\title{
Radiopaque UHMWPE sublaminar cables for spinal deformity correction: Preclinical mechanical and radiopacifier leaching assessment
}

Citation for published version (APA):

Roth, A. K., Boon-Ceelen, K., Smelt, H., van Rietbergen, B., Willems, P. C., van Rhijn, L. W., \& Arts, J. J. (2018). Radiopaque UHMWPE sublaminar cables for spinal deformity correction: Preclinical mechanical and radiopacifier leaching assessment. Journal of Biomedical Materials Research Part B-applied Biomaterials, 106(2), 771-779. https://doi.org/10.1002/jbm.b.33886

Document status and date:

Published: 01/02/2018

DOI:

10.1002/jbm.b.33886

Document Version:

Publisher's PDF, also known as Version of record

\section{Document license:}

Taverne

Please check the document version of this publication:

- A submitted manuscript is the version of the article upon submission and before peer-review. There can be important differences between the submitted version and the official published version of record.

People interested in the research are advised to contact the author for the final version of the publication, or visit the DOI to the publisher's website.

- The final author version and the galley proof are versions of the publication after peer review.

- The final published version features the final layout of the paper including the volume, issue and page numbers.

Link to publication

\footnotetext{
General rights rights.

- You may freely distribute the URL identifying the publication in the public portal. please follow below link for the End User Agreement:

www.umlib.nl/taverne-license

Take down policy

If you believe that this document breaches copyright please contact us at:

repository@maastrichtuniversity.nl

providing details and we will investigate your claim.
}

Copyright and moral rights for the publications made accessible in the public portal are retained by the authors and/or other copyright owners and it is a condition of accessing publications that users recognise and abide by the legal requirements associated with these

- Users may download and print one copy of any publication from the public portal for the purpose of private study or research.

- You may not further distribute the material or use it for any profit-making activity or commercial gain

If the publication is distributed under the terms of Article 25fa of the Dutch Copyright Act, indicated by the "Taverne" license above, 


\title{
Radiopaque UHMWPE sublaminar cables for spinal deformity correction: Preclinical mechanical and radiopacifier leaching assessment
}

\author{
Alex K. Roth ${ }^{(D)}{ }^{1}$ Karlien Boon-Ceelen, ${ }^{2}$ Harold Smelt, ${ }^{2}$ Bert van Rietbergen, ${ }^{3}$ Paul C. Willems, ${ }^{1}$ \\ Lodewijk W. van Rhijn, ${ }^{1}$ Jacobus J. Arts ${ }^{1}$ \\ ${ }^{1}$ Department of Orthopaedic Surgery, Research School CAPHRI, Maastricht University Medical Center, Maastricht, the \\ Netherlands \\ ${ }^{2}$ DSM Biomedical BV, Geleen, the Netherlands \\ ${ }^{3}$ Orthopaedic Biomechanics, Department of Biomedical Engineering, Eindhoven University of Technology, Eindhoven, the \\ Netherlands
}

Received 6 September 2016; revised 24 February 2017; accepted 12 March 2017

Published online 27 March 2017 in Wiley Online Library (wileyonlinelibrary.com). DOI: 10.1002/jbm.b.33886

\begin{abstract}
Polymeric sublaminar cables have a number of advantages over metal cables in the field of spinal deformity surgery, with decreased risk of neurological injury and potential for higher correction forces as the two most predominant. However, currently available polymer cables are radiolucent, precluding postoperative radiological assessment of instrumentation stability and integrity. This study provides a preclinical assessment of a woven UHMWPE cable made with radiopaque UHMWPE fibers. Our primary goal was to determine if the addition of a radiopacifier negatively affects the mechanical properties of UHMWPE woven cables. Tensile mechanical properties were determined and compared to suitable controls. Radiopacity was evaluated and radiopacifier leaching was assessed in vitro and in vivo. Finally, in vivo bismuth organ content was quantified
\end{abstract}

after a 24-week implantation period in sheep. Results show that the mechanical properties of woven UHMWPE cables were not deleteriously affected by the addition of homogenously dispersed bismuth oxide particles within each fiber. Limited amounts of bismuth oxide were released in vitro, well below the toxicological threshold. Tissue concentrations lower than generally accepted therapeutic dosages for use against gastrointestinal disorders, well below toxic levels, were discovered in vivo. These results substantiate controlled clinical introduction of these radiopaque UHMWPE cables. (c) 2017 Wiley Periodicals, Inc. J Biomed Mater Res Part B: Appl Biomater, 106B: 771-779, 2018.

Key Words: radiopaque, UHMWPE fibers, sublaminar cables, bismuth oxide, spinal deformity

How to cite this article: Roth AK, Boon-Ceelen K, Smelt H, van Rietbergen B, Willems PC, van Rhijn LW, Arts JJ. 2018. Radiopaque UHMWPE sublaminar cables for spinal deformity correction: Preclinical mechanical and radiopacifier leaching assessment. J Biomed Mater Res Part B 2018:106B:771-779.

\section{INTRODUCTION}

Pedicle screw usage has become increasingly widespread in the surgical treatment of thoracolumbar spinal disorders. However, there are cases in which pedicle screw usage may be problematic and alternative techniques like sublaminar wiring may be preferred. The insertion of thoracic pedicle screws may be technically demanding when vertebral anatomy is distorted, for example, in scoliosis patients, ${ }^{1}$ which may preclude the placement of thoracic pedicle screws. ${ }^{2}$ Misplaced pedicle screws may lead to serious neurological injury, vascular injury or dural sac tears. ${ }^{3}$ Sublaminar wiring is generally faster than pedicle screw placement, ${ }^{4}$ which may be a reason to favor this technique in the fragile neuromuscular scoliosis patient group ${ }^{4}$ as longer operative time is associated with increased complication rates. Gradually applying tension intraoperatively to the sublaminar wires allows for gradual curve correction. Unlike hooks, ${ }^{5}$ sublaminar wires do not impinge on the spinal canal and are not prone to laminar dislodgement. ${ }^{6}$ Sublaminar wiring may also be a valuable technique in osteoporotic adult spinal deformity patients. Whereas the pull-out strength of pedicle screws decreases dramatically with decreasing bone mineral density, the failure strength using sublaminar wiring remains constant with decreasing bone mineral density. ${ }^{7}$ Pedicle screw augmentation with sublaminar wires has been shown to provide firmer and stiffer fixation in comparison to pedicle screw fixation alone. ${ }^{8}$ Sublaminar wires may therefore also be of great value as a supplementary fixation method.

Drawbacks and concerns related to the use of (metal) sublaminar wires have mainly focused on higher overall neurological complication rates, ${ }^{9}$ which are most often attributed to repeated contusions to the spinal cord during insertion of the rods and tightening of the wires. $^{10}$ 
Multistrand cables were introduced in the early 1990s and offer significant advantages over monofilament wires: the braided cables offer higher static tensile and fatigue strengths. ${ }^{10,11}$ Furthermore, their intrinsic flexibility and pliability allow for greater ease of insertion and tension adjustment. ${ }^{12}$ The penetration of multi-stranded cables into the spinal canal is less than that of monofilament wires. ${ }^{13}$ The improved cable conformance to the shape of the lamina is believed to lead to lower neurological injury rates, although evidence is still lacking.

Soft, flat polymeric sublaminar cable systems have been introduced in the last decade as a further improvement in sublaminar wiring technique. The Universal Clamp system (Zimmer Spine, SAS, Bordeaux, France) consists of a polyester cable and a metallic clamp. ${ }^{14,15}$ The Nesplon cable system (Alfresa Pharma, Osaka, Japan) is an ultra-high molecular weight polyethylene (UHMWPE) cable which is secured using a double-loop sliding knot. $^{16}$ The flat, wide profile of these cable systems distributes contact forces over a greater area, thereby increasing possible corrective forces and lowering the risk of cable pull-out in comparison to metal cables. Both cable systems have been used clinically to treat scoliosis with satisfactory results in both the coronal and sagittal planes. ${ }^{17-19}$ The expected substantially greater fatigue strength of UHMWPE cables in comparison to metal cables has significant clinical importance, as it allows for application in nonsegmental constructs. ${ }^{20}$ Knotted locking allows for sliding of the cable along a spinal rod, and can thereby accompany spinal growth, as evidenced in vivo. ${ }^{21}$ These two properties may potentially allow for the application of UHMWPE cables in a growth-guidance construct for early onset scoliosis patients. However, currently available polymer cable systems are radiolucent, precluding radiologic assessment of instrumentation stability during follow-up.

For this reason, a radiopaque woven UHMWPE cable has been developed using a radiopaque UHMWPE fiber, containing bismuth oxide $\left(\mathrm{Bi}_{2} \mathrm{O}_{3}\right)$ as a radiopacifier (Dyneema Purity $^{\circledR}$ Radiopaque fiber). We have previously assessed these radiopaque UHMWPE cables for biocompatibility and overall instrumentation stability in a large animal model. ${ }^{21}$ In the current study, we aim to determine if the addition of a radiopacifier negatively affects the mechanical properties of UHMWPE woven cables by comparing the mechanical properties of the radiopaque UHMWPE cable to an analog UHMWPE cable without the added radiopacifier (control) in a clinically relevant test setup. A comparison to data published by Dickman et al. $^{22}$ for different sublaminar wire and cable systems is also made. The mechanical properties evaluated for the looped cables (including the knotted locking mechanism) are tensile strength and stiffness, fatigue strength, and creep elongation. Furthermore, we evaluate the radiopacity and assess the in vitro and in vivo leaching of the bismuth oxide radiopacifier. First, in vitro leaching using three different extraction liquids (cyclohexane, ethanol, and saline) for $72 \mathrm{~h}$ at $50^{\circ} \mathrm{C}$ is evaluated. In relation to in vivo leaching, the bismuth oxide content found in different organs after a 24-week implantation period in sheep $^{21}$ is also reported.

\section{MATERIALS AND METHODS \\ Material specification}

Two UHMWPE sublaminar cables were used in this study: (1) a radiopaque 4-mm wide woven UHMWPE sublaminar cable made with Dyneema Purity ${ }^{\circledR}$ Radiopaque fibers [Figure 1(A), will be referred to as DPR cable] and (2) a 4-mm radiolucent analog UHMWPE sublaminar cable made with natural white Dyneema Purity ${ }^{\circledR}$ fibers [Figure 1(B), will be referred to as DP cable]. The thickness of both cables is approximately $0.4 \mathrm{~mm}$ and the effective cross sectional area is approximately $0.64 \mathrm{~mm}^{2}$. To introduce radiopacity, submicron sized bismuth oxide $\left(\mathrm{Bi}_{2} \mathrm{O}_{3}\right)$ particles are physically incorporated and homogeneously distributed in Dyneema Purity ${ }^{\circledR}$ fibers during the gel spinning process [Figure $1(\mathrm{G}){ }^{21}{ }^{21}$ The diameter and number of fibers in both the natural white Dyneema Purity ${ }^{\circledR}$ cables and Dyneema Purity ${ }^{\circledR}$ Radiopaque cables are the same, as is the woven structure of both cables, shown in Figure 1(E,F), respectively. UHMWPE sublaminar cables were manufactured by DSM Biomedical (Geleen, the Netherlands), and sterilized by ethylene oxide treatment before all tests.

A titanium sublaminar cable (Atlas ${ }^{\circledR}$ cable system, Medtronic Sofamor Danek, Memphis) was used as a control in static tensile tests [Figure 1(C)]. Data published by Dickman et al. $^{22}$ for the Atlas ${ }^{\circledR}$ titanium sublaminar cable, and the SecureStrand ${ }^{\mathrm{TM}}$ cable system (Smith \& Nephew, Memphis TN) will be used as a comparison for creep elongation and fatigue strength values. The SecureStrand ${ }^{\mathrm{TM}}$ is a 1-mm diameter braided UHMWPE cable with 120 filaments/fiber and 8 fibers braided in diamond cable fashion. The titanium Atlas cable ${ }^{\circledR}$ is a twisted 1-mm diameter cable, consisting of 49 filaments $(7 \times 7)$ with an effective cross sectional area of approximately $0.38 \mathrm{~mm}^{2}$.

Mechanical tests were performed using looped samples including the locking mechanism, which closely resembles the clinical application as a sublaminar wire [Figure 1(D)]. A modified double-looped sliding knot is used to secure the tested UHMWPE cables. ${ }^{21}$ The double-looped sliding knot is tied off using a single square knot throw, tensioned using a custom tensioning device to $500 \mathrm{~N}$, and finally tied-off using six additional square knot throws. The titanium sublaminar cable was tightened and secured using a metal crimp, according to the manufacturer's recommendations.

\section{Radiopacity assessment}

Digital radiographs of the radiolucent UHMWPE cable (DP), radiopaque UHMWPE cable (DPR) and the titanium Atlas ${ }^{\circledR}$ cable were acquired using a clinical computed radiography machine (Siemens Multix Fusion Digital, Siemens Healthcare $\mathrm{GmbH}$, Erlangen, Germany). Images were acquired using an acceleration voltage of $45 \mathrm{kV}$ and a tube current-exposure time product of $4.2 \mathrm{mAs}$. Radiopacity was quantified relative to an aluminum step wedge $(0.4-5.2 \mathrm{~mm}$ in $0.4-\mathrm{mm}$ steps, Artinis Medical Systems, Elst, the Netherlands), which was placed beside the cables during image acquisition. Regional 

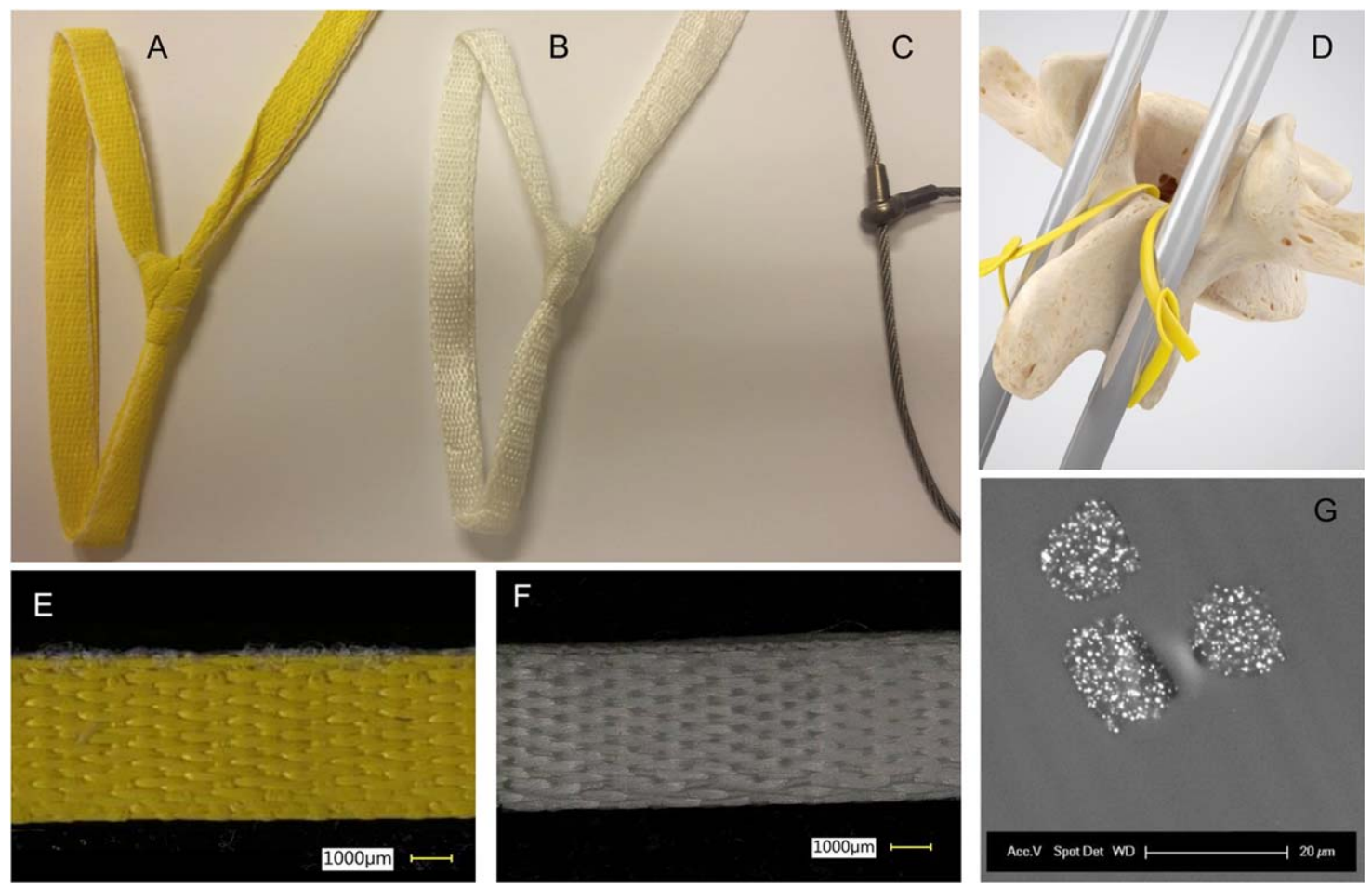

FIGURE 1. (A) Radiopaque UHMWPE (DPR) cable (B) radiolucent analog UHMWPE (DP) cable (C) titanium Atlas ${ }^{\circledR}$ cable. (D) Illustration of the application of the DPR cable as a sublaminar wire. Woven structure comparison between (E) DPR cable and (F) the DP cable. (G) Backscatter scanning electron microscopy (SEM) image showing the homogenously distributed submicron sized bismuth oxide particles within the fiber (acceleration voltage $25 \mathrm{kV}$ ).

gray-value intensities were determined using Synedra View Personal (Synedra Information Technologies, Innsbruck, Austria) by two independent observers (A.R. and K.B.) performing two measurements each. The radiopacity was quantified for the following cables and views: (1) DP cable lateral/side view, (2) DPR cable lateral/side view, (3) knot, (4) DPR cable frontal view four layers, (5) titanium Atlas ${ }^{\circledR}$ cable, and (6) the titanium cable crimp.

\section{Mechanical testing}

Tensile strength, tensile stiffness, fatigue strength, and creep elongation were determined for looped UHMWPE (DPR and DP) cables using various material testing machines fitted with Clevis grips [Figure 2(A)]. The diameter of the pins was $10 \mathrm{~mm}$ and the distance between the longitudinal axes of the two parallel pins was $40 \mathrm{~mm}$. Tensile strength and stiffness of the loops were determined at an actuator displacement speed of $1 \mathrm{~mm} / \mathrm{s}$. The stiffness was determined from the initial (linear) slope of the load-displacement curve between 100 and $500 \mathrm{~N}$. Load was divided by a factor two when calculating the stiffness to account for load distribution among both legs of the loop. Fatigue strength, defined as the highest peak load at which three consecutive samples did not fail during 5 million cycles of loading, was determined using both a servo-hydraulic material testing machine (MTS Bionix 858, MTS, Eden Prairie, MN) and an electrodynamic material testing machine (MTS Acumen 3, MTS, Eden Prairie, MN). The cycle minimum load was $10 \%$ of the peak load. Testing on the servo-hydraulic machine was performed at a frequency of $5 \mathrm{~Hz}$, while testing on the electrodynamic machine was performed at $10 \mathrm{~Hz}$.

Creep was determined at $37^{\circ} \mathrm{C}$ and at room temperature using double-spindle materials test machines. A Zwick Z010 (Zwick GmbH, Ulm, Germany) machine was used to perform tests at room temperature, while a Zwick 1484 (Zwick GmbH, Ulm, Germany) machine fitted with a climate chamber (ETE 220 LN2, Weiss Technik, Vienna, Austria) was used to perform tests at $37^{\circ} \mathrm{C}$. At $37^{\circ} \mathrm{C}$, a load of $500 \mathrm{~N}$ was applied and held for $72 \mathrm{~h}$, and creep elongation was calculated from a preload of $100 \mathrm{~N}$. At room temperature, a load of $475 \mathrm{~N}$ was applied and held for $24 \mathrm{~h}$. Creep elongation was calculated from a preload of $45 \mathrm{~N}$, in order to make a comparison to data published by Dickman et al. ${ }^{22}$ For comparative purposes, uniaxial tensile strength of individual UHMWPE fibers and the woven UHMWPE cables without knot was determined with a Zwick 1474 material testing machine using pneumatic fiber grips [for fibers, Figure $2(\mathrm{C})$ ] and rope grips fitted with load reduction rollers for cables without knot [Figure 2(B)]. These tests were performed with actuator displacement speeds of 150 and $250 \mathrm{~mm} / \mathrm{min}$, respectively.

A comparison of tensile and fatigue strength, stiffness, and creep elongation values was made using the Mann-Whitney $U$ test for independent samples. Statistical significance was set at $p<0.05$. Statistical analyses were performed using standard software (IBM SPSS Statistics, Version 21.0; IBM, Armonk, NY). 


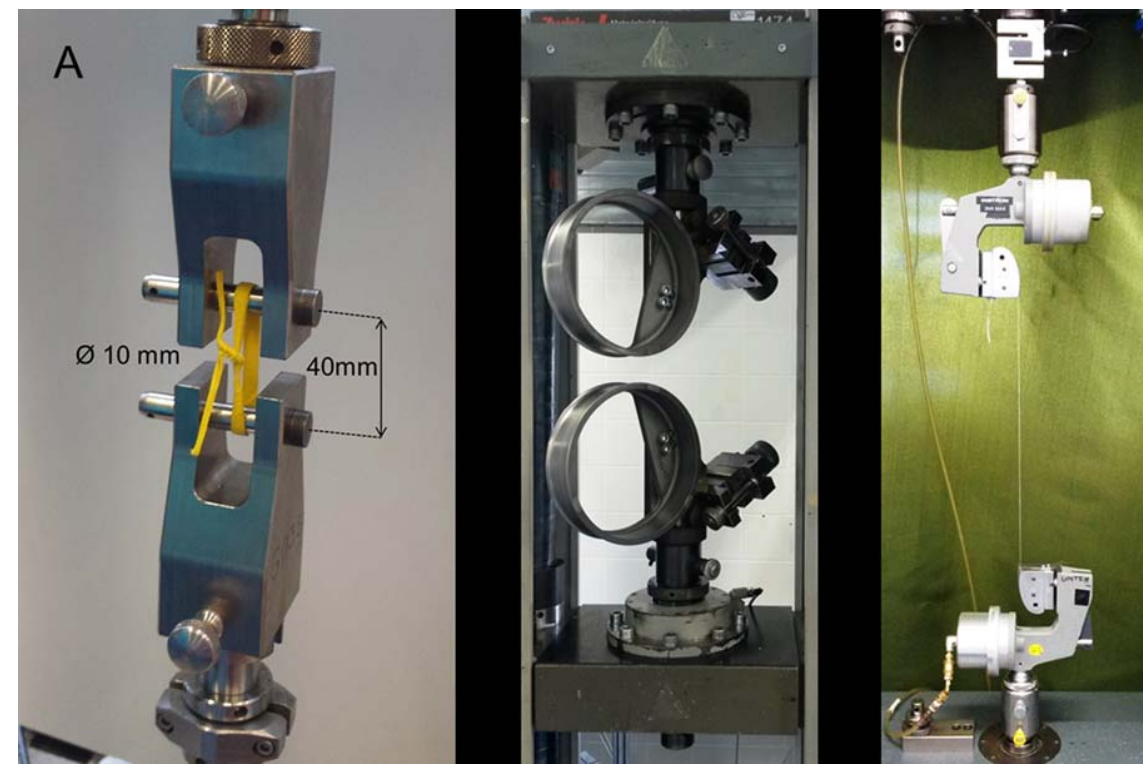

FIGURE 2. (A) The Clevis-grips used to test looped samples. (B) The rope grips and load reduction rollers used to quantify the tensile strength of single cable strands. (C) The pneumatic fiber grips used to test individual fibers.

\section{Radiopacifier leaching: in vitro analysis}

In vitro leaching of bismuth oxide particles from the DPR cable was evaluated in triplicate in three different extraction

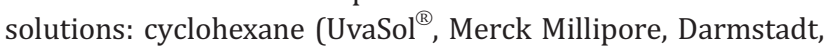
Germany), ethanol (LiChrosolv ${ }^{\circledR}$, Merck Millipore, Darmstadt, Germany), and $0.9 \%$ saline ( $\mathrm{NaCl}$ min. 99.5\%, Merck Millipore, Darmstadt, Germany in Milli-Q water). Samples were prepared according to ISO 10993-12:2007, which prescribes an extraction ratio of $0.2 \mathrm{~g}$ of solid material per milliliter of extraction fluid. Extraction was performed using intact cable samples (ca. $1.0 \mathrm{~g}$ ) in closed glass bottles (vessels for headspace gas chromatography) in a GC oven at $50 \pm 1^{\circ} \mathrm{C}$ for $72( \pm 1) \mathrm{h}$. The samples were shaken twice a day for circulation of the extraction solutions. After extraction at $50^{\circ} \mathrm{C}$ for $72 \mathrm{~h}$ and removal of the cable sample, the extraction liquid was evaporated in the presence of sulfuric acid $\left(\mathrm{H}_{2} \mathrm{SO}_{4}\right.$, Suprapur ${ }^{\circledR}$, Merck Millipore, Darmstadt, Germany). After full evaporation, the remaining residue was dissolved in diluted nitric acid $\left(\mathrm{HNO}_{3}\right.$, Suprapur ${ }^{\circledR}$, Merck Millipore, Darmstadt, Germany). Bismuth content was determined in these samples using elemental analysis via inductively coupled plasma atomic emission spectroscopy (ICP-AES, iCAP6500, ThermoFisher Scientific, Waltham, MA).

\section{Radiopacifier leaching: in vivo analysis}

DPR sublaminar cables were implanted in 12 immature sheep at 5 thoracolumbar spinal levels. A detailed description of the operative technique has previously been published. ${ }^{21}$ All animals were sacrificed 24 weeks postoperatively. The animal procedures were approved by the Animal Ethical Committee of the Maastricht University Medical Center (approval number: DEC 2011-122). Liver, kidney, cerebral spinal fluid, and muscle biopsies (adjacent to instrumentation) were taken at random from three animals. Samples from three unoperated control animals were also analyzed to attain natural reference values. All samples were microwave-digested in 65\% nitric acid $\left(\mathrm{HNO}_{3}\right.$, Suprapur ${ }^{\circledR}$, Merck Millipore, Darmstadt, Germany). Liver and kidneys were homogenized prior to digestion. Bismuth content was determined using inductively coupled plasma mass spectrometry (ICP-MS, Perkin Elmer DRC-e, Waltham, MA).

\section{RESULTS}

\section{Radiopacity assessment}

A radiograph of the DP cable, DPR cables placed at different orientations, and the titanium Atlas ${ }^{\circledR}$ cable along with an aluminum (Al) step wedge is depicted in Figure 3(A). The woven UHMWPE cables have a flat, wide profile and are secured using a double-looped sliding knot, resulting in a double-stranded loop at all locations. Thus, radiopacity is dependent on the view angle and the number of stacked cable layers. For the DPR cable, radiopacity values in the lateral view (2) and for the knot (3) are similar to the titanium Atlas ${ }^{\circledR}$ cable. In the frontal view, radiopacity is lower, but increases with an increasing number of stacked layers. All aluminum-equivalent radiopacity values are shown in Table I. A lateral radiograph showing the in vivo radiopacity of the DPR cables as used in a lumbar construct along with titanium pedicle screws and 4.75-mm cobalt chromium rods in an immature sheep model ${ }^{21}$ is given in Figure 3(B).

\section{Mechanical testing}

Results of mechanical tests are summarized in Table II. The tensile strength and the fatigue strength of both UHMWPE cables (DPR and DP) are substantially greater than both the titanium Atlas $^{\circledR}$ cable and the SecureStrand ${ }^{\mathrm{TM}}$ cable. The measured tensile stiffness of the DPR and DP cables is greater than or at least comparable to the stiffness of the titanium cable $(p=0.008, p=0.076)$. The stiffness of the SecureStrand $^{\mathrm{TM}}$ cable is lower than all other cable systems, 


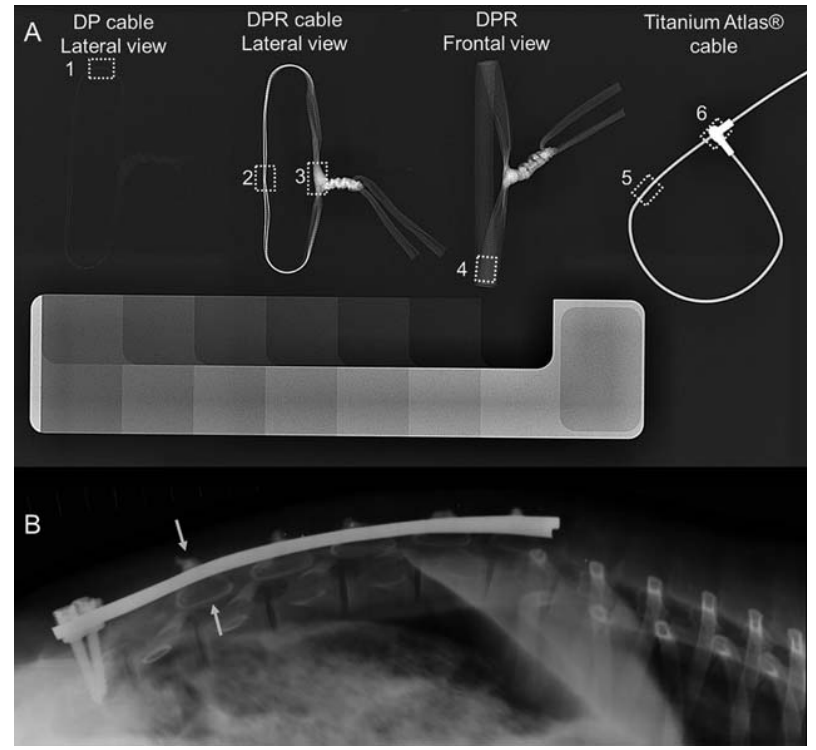

FIGURE 3. (A) Radiograph ( $45 \mathrm{kV} 4.2 \mathrm{mAs}$ ) comparing the radiopacity of the DP cable (view 1) to different views of DPR cable (views 2-4), and the titanium Atlas ${ }^{\circledR}$ cable (views 5-6) relative to a 0.4:0.4:5.2-mm aluminum step wedge. (B) In vivo lateral radiograph (90 kV $80 \mathrm{mAs}$ ) of DPR cables (T12-L3) in a lumbar spinal construct along with dual pedicle screws (L5) and dual $4.75-\mathrm{mm}$ cobalt chromium rods in an immature sheep model.

which may be attributable to a number of factors, including different pretension levels, a different number of fibers, different locking techniques, and different behavior between woven and braided constructions. Creep elongation is greater for all UHMWPE cables (DPR, DP, and SecureStrand ${ }^{\mathrm{TM}}$ ) in
TABLE I. Aluminum Equivalent Radiopacity Values for the Regions Shown in Figure 3(A)

\begin{tabular}{llr}
\hline DP cable & 1. Lateral view & $0.9 \pm 0.0 \mathrm{~mm} \mathrm{Al}$ \\
DPR cable & 1. Lateral view & $7.0 \pm 0.2 \mathrm{~mm} \mathrm{Al}$ \\
& 1. Knot & $6.5 \pm 0.2 \mathrm{~mm} \mathrm{Al}$ \\
& $\begin{array}{l}\text { 1. Frontal view } \\
\quad \text { (four layers) }\end{array}$ & $1.8 \pm 0.0 \mathrm{~mm} \mathrm{Al}$ \\
Titanium & 1. Lateral/frontal view & $7.1 \pm 0.3 \mathrm{~mm} \mathrm{Al}$ \\
Atlas $^{\circledR}$ cable & & \\
& 1. Cable crimp & $12.6 \pm 0.1 \mathrm{~mm} \mathrm{Al}$ \\
\hline
\end{tabular}

Values were determined by two independent observers performing two measurements each.

comparison to the titanium cable. Creep elongation for the DP and DPR cables are lower than for the SecureStrand ${ }^{\mathrm{TM}}$ cable after sustaining a $475-\mathrm{N}$ load for $24 \mathrm{~h}$ at room temperature.

Comparing the DPR cable to the DP cable, only slight differences are observed. The tensile strength of the DP cable is greater than the strength of the DPR cable $(p=0.016)$, while there are no significant differences in tensile stiffness $(p=0.917)$, in strength of single strands $(p=0.307)$, or in strength of individual fibers $(p=0.917)$. Representative force-displacement curves are shown in Figure 4(A). The fatigue strength of the DPR cable (run-out at 5 million cycles) is slightly higher than for the DP cable, although this difference is negligible. Different overall fatigue behavior is observed, which is best illustrated on a load-cycle number curve plotted on a log-scale [Figure 4(B)]. Creep elongation after $24 \mathrm{~h}$ at room temperature $(p=0.009)$ and after $72 \mathrm{~h}$ at $37^{\circ} \mathrm{C}(p=0.047)$ are both slightly lower for the DPR

TABLE II. Summary of the Results of All Performed Mechanical Tests

\begin{tabular}{|c|c|c|c|c|}
\hline & $\begin{array}{l}\text { UHMWPE Sublaminar } \\
\text { Cable Made With } \\
\text { Dyneema Purity }^{\circledR} \\
\text { Radiopaque Fibers } \\
\text { (DPR Cable) }\end{array}$ & $\begin{array}{l}\text { UHMWPE Sublaminar } \\
\text { Cable Made With } \\
\text { Dyneema Purity } \\
\text { Fibers (DP Cable) }\end{array}$ & $\begin{array}{l}\text { Atlas }^{\circledR} \text { Titanium } \\
\text { Cable (Medtronic, } \\
\text { Memphis, TN) }\end{array}$ & $\begin{array}{c}\text { SecureStrand }^{\mathrm{TM}} \\
\text { (Smith \& Nephew } \\
\text { Richards, Memphis, TN) }\end{array}$ \\
\hline $\begin{array}{l}\text { Tensile Strength } \\
\text { Loop }\end{array}$ & $2232 \pm 105 \mathrm{~N}^{\mathrm{a}, \mathrm{b}}$ & $2493 \pm 143 \mathrm{~N}^{\mathrm{a}, \mathrm{c}}$ & $\begin{array}{c}1100 \pm 54 \mathrm{~N}^{\mathrm{b}, \mathrm{c}} \\
(n=5) \\
1005 \pm 49 \mathrm{~N}^{\mathrm{d}}\end{array}$ & $1565 \pm 71 \mathrm{~N}^{\mathrm{d}}$ \\
\hline Tensile Stiffness Loop & $\begin{array}{c}503 \pm 39 \mathrm{~N} / \mathrm{mm}^{\mathrm{b}} \\
(n=5)\end{array}$ & $\begin{array}{c}492 \pm 47 \mathrm{~N} / \mathrm{mm} \\
(n=5)\end{array}$ & $\begin{array}{l}428 \pm 28 \mathrm{~N} / \mathrm{mm}^{\mathrm{b}} \\
(n=5) \\
497 \pm 32 \mathrm{~N} / \mathrm{mm}^{\mathrm{d}}\end{array}$ & $322 \pm 51 \mathrm{~N} / \mathrm{mm}^{\mathrm{d}}$ \\
\hline $\begin{array}{l}\text { Fatigue strength (runout } \\
\text { at } 5 \text { million cycles) }\end{array}$ & $\begin{array}{c}1559 \mathrm{~N} \\
(n=3)\end{array}$ & $\begin{array}{c}1500 \mathrm{~N} \\
(n=3)\end{array}$ & $<45 \mathrm{~N}^{\mathrm{d}}$ & $\begin{array}{c}578 \mathrm{~N}^{\mathrm{d}} \\
\text { (3 million cycles) }\end{array}$ \\
\hline $\begin{array}{r}\text { Creep elongation }(475 \mathrm{~N} \\
\left.\text { static load, } 24 \mathrm{~h}, 20^{\circ} \mathrm{C}\right)\end{array}$ & $\begin{array}{c}2.23 \pm 0.20 \%{ }^{a} \\
(n=5)\end{array}$ & $2.69 \pm 0.20 \%{ }^{a}$ & $\begin{array}{l}0.74 \%{ }^{d} \\
(356 N)\end{array}$ & $3.22 \%^{d}$ \\
\hline $\begin{array}{l}\text { Creep elongation }(500 \mathrm{~N} \\
\left.\text { static load, } 24 \mathrm{~h}, 37^{\circ} \mathrm{C}\right)\end{array}$ & $2.67 \pm 0.29 \%^{a}$ & $\begin{array}{c}3.01 \pm 0.25 \% \%^{a} \\
(n=5)\end{array}$ & $\mathrm{n} / \mathrm{a}$ & $\mathrm{n} / \mathrm{a}$ \\
\hline $\begin{array}{r}\text { Creep elongation }(500 \mathrm{~N} \\
\left.\text { static load, } 72 \mathrm{~h}, 37^{\circ} \mathrm{C}\right)\end{array}$ & $\begin{array}{c}3.03 \pm 0.32 \%{ }^{a} \\
(n=5)\end{array}$ & $\begin{array}{c}3.39 \pm 0.28 \%{ }^{a} \\
(n=5)\end{array}$ & $\mathrm{n} / \mathrm{a}$ & $\mathrm{n} / \mathrm{a}$ \\
\hline $\begin{array}{l}\text { Tensile strength } \\
\text { single fiber }\end{array}$ & $\begin{array}{c}40.5 \pm 1.2 \mathrm{~N} \\
(n=5)\end{array}$ & $\begin{array}{c}40.7 \pm 0.4 \mathrm{~N} \\
(n=5)\end{array}$ & $\mathrm{n} / \mathrm{a}$ & $\mathrm{n} / \mathrm{a}$ \\
\hline $\begin{array}{l}\text { Tensile strength } \\
\text { single strand }\end{array}$ & $\begin{array}{c}1146 \pm 60 \mathrm{~N} \\
(n=10)\end{array}$ & $\begin{array}{c}1170 \pm 50 \mathrm{~N} \\
(n=10)\end{array}$ & $\mathrm{n} / \mathrm{a}$ & $\mathrm{n} / \mathrm{a}$ \\
\hline
\end{tabular}

a A statistically significant difference $(p<0.05)$ between the DPR and DP cable.

${ }^{\mathrm{b}}$ A statistically significant difference $(p<0.05)$ between the DPR and titanium cable.

${ }^{\mathrm{c}}$ A statistically significant difference $(p<0.05)$ between the DP and the titanium cable.

${ }^{\mathrm{d}}$ A value taken from Dickman et al. ${ }^{22}$; hence, no statistical calculations were performed. Missing data was not available (n/a) in literature. 

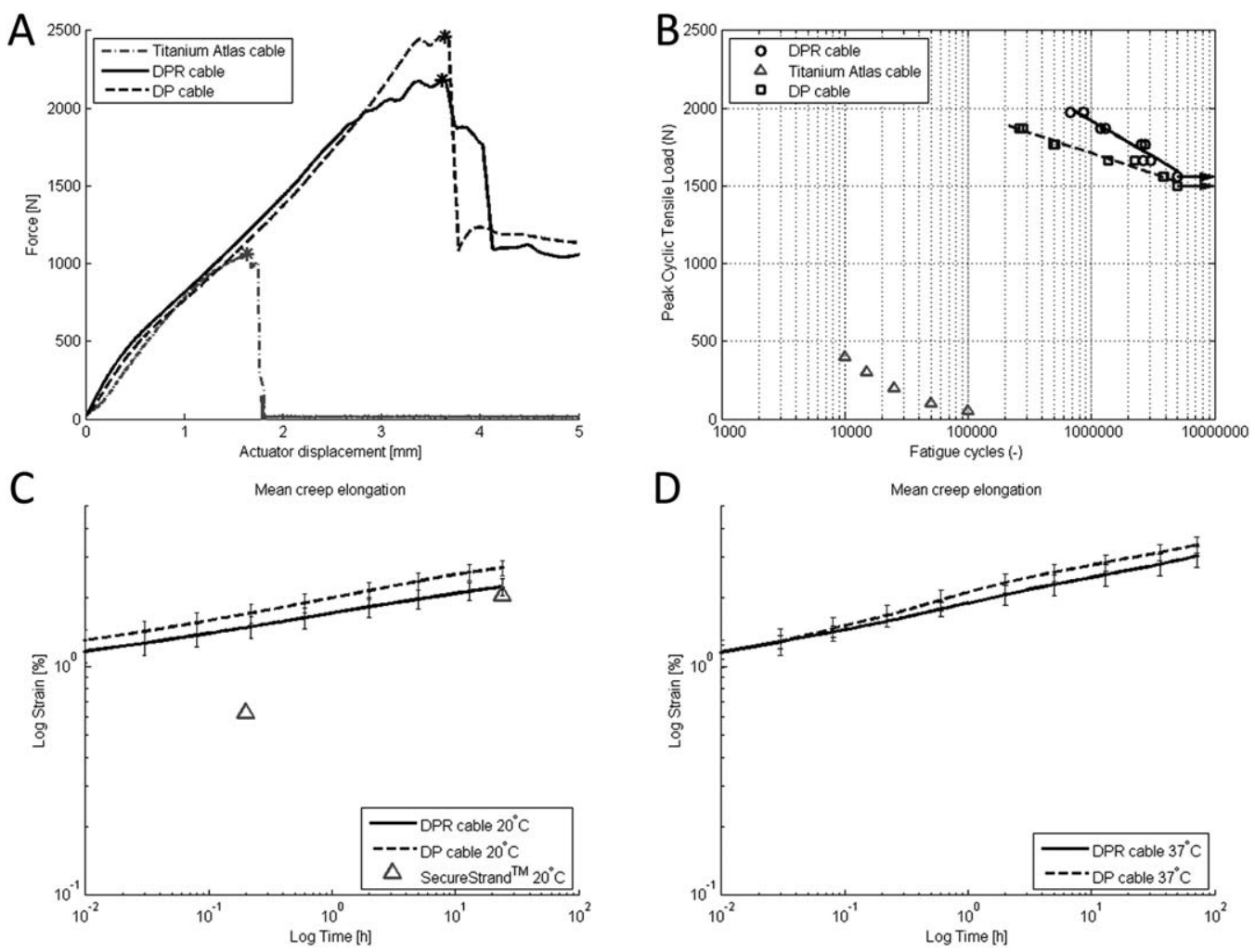

FIGURE 4. (A) Representative load-displacement curves for the compared cables in quasi-static tension, (B) Load-cycle to failure curve illustrating the results of the dynamic fatigue tests. Log-log strain-time curves illustrating the results of creep tests at $37^{\circ} \mathrm{C}(\mathrm{C})$ and at room temperature (D).

cable in comparison to the DP cable. Creep elongation after $24 \mathrm{~h}$ at $37^{\circ} \mathrm{C}$ is only marginally higher than at room temperature for both the DP and DPR cable. Differences between the two cables and the majority of the elongation occur primarily in the first hour of testing, as is illustrated in log-log scale load-time curves [Figure 4(C,D)].

\section{Radiopacifier leaching: in vitro analysis}

The bismuth content in extraction liquids is shown in Table III. No significant difference was observed in bismuth content between the cyclohexane and ethanol extraction liquid groups. The bismuth content found in the saline samples was significantly lower than both the cyclohexane and ethanol conditions.

TABLE III. Bismuth Content (Average of 3 Samples) in Various Extraction Liquids After $72 \mathrm{~h}$ at $50^{\circ} \mathrm{C}$, as Determined by ICP-AES, Expressed Quantitatively and as a Percentage of the Total Bismuth Content Within the Fiber

\begin{tabular}{llcc}
\hline In Vitro Analysis & $\begin{array}{c}\text { Leaked Bismuth } \\
\text { Content } \\
{[\mu \mathrm{g} / \mathrm{g} \text { Fiber] }}\end{array}$ & $\begin{array}{c}\text { Leaked Bismuth } \\
\text { Percentage } \\
{[\%]}\end{array}$ \\
\hline Cyclohexane & Blank & $<0.005$ \\
Ethanol & Test & $6.8 \pm 2.8$ & 0.0034 \\
Saline & Blank & $<0.005$ & \\
& Test & $5.9 \pm 1.5$ & 0.0030 \\
& Blank & $<0.005$ & \\
& Test & $1.7 \pm 0.6$ & 0.00085 \\
\hline
\end{tabular}

\section{Radiopacifier leaching: in vivo analysis}

The bismuth content in tissue biopsies revealed that the highest concentration of bismuth was found in the kidneys, with considerably lower amounts found in the liver and muscle biopsies, as is expected based on literature ${ }^{23}$ (Table IV). Bismuth levels below the limit of detection $(<5 \mu \mathrm{g} / \mathrm{kg})$ were found in all biopsies taken from unoperated control animals. The bismuth levels detected in the kidneys in this study are below levels found after therapeutic dosages of orally administered bismuth compounds in rats $(15-30 \mu \mathrm{g} /$ g) ${ }^{24,25}$ and far below toxic levels. ${ }^{26}$

\section{DISCUSSION}

In this study, we compared the mechanical properties of radiopaque UHMWPE cables to a radiolucent analog UHMWPE cable, a titanium cable and to available literature values for another UHMWPE cable. Furthermore, we assessed their radiopacity, and evaluated the in vitro and in vivo leaching of the bismuth oxide radiopacifier.

The functional mechanical properties tested of both UHMWPE cables (DPR and DP cables) are superior to metal cables in terms of tensile and fatigue strength, and comparable in terms of tensile stiffness. The mechanical properties of the DPR cable have not been deleteriously affected by the addition of homogenously dispersed bismuth oxide particles within each fiber, as was shown by the comparison to the DP cable. The DPR cable, DP cable, and the Secure Strand ${ }^{\mathrm{TM}}$ cable (all UHMWPE cables) exhibit higher creep elongation 
TABLE IV. Bismuth Content in Various Tissues (Measured in Duplicate) After a 24-Week Implantation Period in Sheep as Determined by ICP-MS

\begin{tabular}{|c|c|c|c|c|c|c|c|c|}
\hline \multirow{2}{*}{$\frac{\text { In Vivo Analysis }}{\text { Animal } 1}$} & \multicolumn{2}{|c|}{$\begin{array}{c}\text { Kidney } \\
{[\mu \mathrm{g} / \mathrm{g} \text { tissue }]}\end{array}$} & \multicolumn{2}{|c|}{$\begin{array}{c}\text { CSF } \\
{[\mu \mathrm{g} / \mathrm{g} \text { tissue }]}\end{array}$} & \multicolumn{2}{|c|}{$\begin{array}{c}\text { Liver } \\
\text { [ } \mu \mathrm{g} / \mathrm{g} \text { tissue] }\end{array}$} & \multicolumn{2}{|c|}{$\begin{array}{c}\text { Muscle } \\
{[\mu \mathrm{g} / \mathrm{g} \text { tissue }]}\end{array}$} \\
\hline & 4.5 & 4.4 & 0.0085 & 0.0057 & 0.290 & 0.280 & 0.063 & 0.175 \\
\hline Animal 2 & 5.1 & 5.1 & 0.0054 & 0.0064 & 0.362 & 0.355 & 0.023 & 0.039 \\
\hline Animal 3 & 4.0 & 4.1 & $\mathrm{n} / \mathrm{a}$ & $\mathrm{n} / \mathrm{a}$ & 0.335 & 0.331 & 0.094 & 0.060 \\
\hline Control animals & $<0.005$ & $<0.005$ & $<0.005$ & $<0.005$ & $<0.005$ & $<0.005$ & $<0.005$ & $<0.005$ \\
\hline
\end{tabular}

than the currently most commonly used metal cables. Possible clinical implications, in the specific context of spinal deformity correction, would be difficult to extrapolate from these results without a better understanding of actual in situ forces present. In this respect, it should be mentioned that no loss of function was observed during the related large animal model study in which the DPR cables were used. ${ }^{21}$ Moreover, relevant literature also reports that no loss of correction was observed after 2 years in adolescent idiopathic scoliosis patients treated with hybrid constructs consisting of both pedicle screws and UHMWPE sublaminar cables, as reported by Imagama et al. ${ }^{17}$ All in all, both the DPR and DP cables are deemed suitable for clinical application.

Some slight differences in the mechanical properties of the radiopaque UHMWPE (DPR) cable and its radiolucent analog (DP cable) were observed, which we attribute to different behavior occurring within the knot rather than the materials' intrinsic properties. The knot appears to play a crucial role in the failure mechanism and during creep behavior. During loading, the knot is gradually tightened. As a result, compression of the cable strands passing through the sliding knot occurs, which consistently leads to stress concentration and failure in this region. As there was no difference in tensile strength of individual fibers or cables without knot, we therefore conclude that the difference in knotted samples arises due to slightly different knottightening behavior. This theory is further substantiated by evaluating creep behavior; the measured elongation is a combination of two factors: macroscopic elongation through tightening of the knot and microscopic creep occurring within each fiber. In this context, the observed slight difference between the DPR and DP cables occurs primarily during the first hour of testing, which again points toward the macroscopic knot tightening behavior as the biggest influencing factor. Nonetheless, the most important observation is that the mechanical properties of both DPR and DP cables are within the same range and higher than the controls.

The gradual tightening of the knot also influences the stiffness of the looped UHMWPE cables; whereas the stiffness of single UHMWPE fibers is approximately $131 \mathrm{GPa}$, a knotted loop has a stiffness of approximately $22 \mathrm{GPa}$. By introducing the knot, the strength is also reduced from 1.8 $\mathrm{GPa}$ to approximately $900 \mathrm{MPa}$. These normalized values are lower than the normalized values for the titanium cable (stiffness $62 \mathrm{GPa}$ and strength $1.4 \mathrm{GPa}$ ), due to the differences in the cross-sectional fiber configuration and the difference in means of fixation (knot versus crimped sleeve). The UHMWPE cables are envisioned to be applied as sliding anchor members in a growth guidance system for early onset scoliosis. This particular application precludes the use of a clamp or crimp and necessitates the use of a knot as the means of fixation in order to allow for free longitudinal sliding. Although the knot has a substantial effect on the mechanical properties, the functional mechanical properties of the looped UHMWPE cables remain superior or at least equal to the crimped titanium cables. Moreover, the flexibility and pliability of UHMWPE fibers allows for the production of woven cables with a wide profile. This results in a larger contact area and lower contact stresses, while retaining sufficient functional strength for the application.

The radiopacity of the DPR cable in the lateral view is similar to the round titanium cable. The radiopacity is directly correlated with the thickness of the cable, which implies that the radiopacity increases going from frontal view, toward the lateral view and the knot. For the intended application in EOS patients, the low-profile was the most important requirement kept in mind during the cable design process. This implies that radiological assessment would be best performed using lateral radiographs for spinal applications. Lateral radiographs provide adequate potential for assessing cable and complete construct integrity, as we have experienced in our previously described animal studies. ${ }^{21}$ When radiopaque UHMWPE fibers are used to produce a woven or braided cable, its radiopacity will be highly dependent on the number of fibers used, their structural configuration, and the amount of surrounding tissue at the specific location.

The use of bismuth as a radiopacifying agent within biomedical implants is appealing due to its high atomic number $\left(Z_{\mathrm{Bi}}=83\right)$, and its well-known biological tolerance. ${ }^{27}$ Bismuth (III) complexes are renally clearable via metallothionine, a cysteine-rich protein abundant in the kidneys which has a preferential affinity for bismuth over other elements, regardless of $\mathrm{pH}^{28}$ Bismuth oxide is routinely used as a radiopacifying agent in root end fillers for endodontic surgery in a derivation of Portland cement known as mineral trioxide aggregate (MTA). ${ }^{29,30}$ The use of various other bismuth compounds as radiopacifying agent in orthopedic bone cements has also been proposed and investigated. ${ }^{31,32}$ Concerning potential toxicity, the in vitro toxicity of bismuth oxide has been well described, with no concerning results reported. No toxicity was observed after administration of bismuth oxide to human peripheral lymphocytes ${ }^{33}$ and human proximal tubular cells, ${ }^{34}$ even at the highest 
administered doses [1000 $\mu \mathrm{g} / \mathrm{mL}$ and $100 \mu M(\sim 40 \mu \mathrm{g} /$ $\mathrm{mL}$ ), respectively]. The highest evaluated concentrations in literature mentioned above were substantially higher than the maximum concentration of bismuth found in our in vivo study $(\sim 5 \mu \mathrm{g} / \mathrm{g}$ of tissue, which is approximately equal to 5 $\mu \mathrm{g} / \mathrm{mL}$, assuming a density of $1.05 \mathrm{~g} / \mathrm{mL}$ for all tissue biopsies). Furthermore, murine fibroblasts exposed to Portland cement containing $15 \%$ wt bismuth oxide did not show genotoxic or cytotoxic effects in comparison to a control mineral trioxide aggregate. ${ }^{35}$

A no-observed-adverse-effect level (NOAEL) for repeated doses of orally administered pure bismuth has previously been established for rats at $1000 \mathrm{mg} / \mathrm{kg}$ body weight per day by Sano et al. ${ }^{36} \mathrm{~A}$ tolerable intake value (TI) can be calculated for humans and the intended manner of administration [intramuscular implantation (IM)] by dividing the known NOAEL by the modifying factor, which is the product of three uncertainty factors in accordance with ISO 1099317. For the intended application, we herein define a first uncertainty factor of 10 for interindividual variations, a second uncertainty factor of 10 for interspecies variation, and a third uncertainty factor of 10 for the different administration route (IM), so that the TI for intended application in humans is $1 \mathrm{mg} / \mathrm{kg}$ body weight per day. A maximum concentration of $10 \mu \mathrm{g} / \mathrm{g}$ fiber was found to leach during the in vitro study. If $5 \mathrm{~g}$ of cable (ca. $5 \mathrm{~m}$, or dual cables at $10 \mathrm{spi}$ nal levels) is implanted in a patient, a maximum of $50 \mu \mathrm{g}$ of $\mathrm{Bi}_{2} \mathrm{O}_{3}$ could become biologically available, based on our in vitro leaching study. In the worst case scenario where this amount would all leach out in 1 day, the margin-of-safety would be 1000 for a person of $50 \mathrm{~kg}$. Thus, the amount of bismuth found to leach out of the cable during the in vitro studies is no cause for concern.

Toxicity after acute or chronic exposure to high concentrations of therapeutic bismuth compounds for the treatment of gastrointestinal disorders has been reported. Prolonged exposure to high concentrations of waterinsoluble lipophilic bismuth compounds, particularly bismuth subgallate, has been reported to lead to toxicity in the form of encephalopathy. ${ }^{23,37,38}$ Cerebral spinal fluid (CSF) bismuth concentration is most reflective of the patient's condition, with reports of CSF concentrations of approximately 50-60 $\mu \mathrm{g} / \mathrm{L}$ in bismuth encephalopathy patients. ${ }^{23}$ In the current study, bismuth levels below $10 \mu \mathrm{g} / \mathrm{L}$ were found in the CSF after 24 weeks and all animals behaved normally; therefore, neurotoxicity is no cause for concern.

Nephrotoxicity has been reported to occur after acute overdose with different bismuth compounds, and is mostly associated with water-soluble, organic bismuth compounds such as colloidal bismuth subcitrate, bismuth sodium tri- or thioglycollamate, bismuth subsalicylate, and bismuth sodium tartrate. ${ }^{23,38}$ The kidney bismuth levels detected in this study are lower than bismuth levels found after therapeutic dosages of orally administered bismuth compounds (15-30 $\mu \mathrm{g} / \mathrm{g}),{ }^{24,25}$ and are far below toxic levels ${ }^{26}$ and the herein established TI.

This study has a few limitations. First, all mechanical tests were performed under dry conditions, which is not representative of the wet conditions in the human body. However, UHMWPE fibers are not hygroscopic and their mechanical properties are therefore typically hardly affected. Second, in vitro leaching experiments were performed with no load applied to the cables; loading may increase radiopacifier leaching. Furthermore, most properties were not measured at body temperature, but it is expected that the differences at room and body temperature are only marginal. Creep was measured at body temperature, because it is known to be sensitive to temperature. Testing the fatigue strength on two different machines is also a limitation. Creep and fatigue tests have not been performed for cables without the knot or for individual fibers. However, we intentionally focused on the clinical application and comparison to other sublaminar cable systems rather than the fundamental comparison between the DPR and DP cables and fibers per se. In that regard, both the DPR and the DP cables perform equally well and show similar differences in comparison to the other assessed cables.

\section{CONCLUSION}

The mechanical properties of the DPR cable have not been deleteriously affected by the addition of homogenously dispersed bismuth oxide particles within each fiber, and are superior to the compared sublaminar wire systems in terms of tensile and fatigue strength, while possessing a stiffness at least comparable to metal cables. UHMWPE cables do exhibit higher creep elongation in comparison to metal cables, but so far no negative clinical implications have been reported. Limited amounts of bismuth oxide are released through leaching in vitro, which are well below established tolerable intake. Tissue concentrations lower than therapeutic dosages as used against gastrointestinal disorders, and well below toxic levels, were found after 24 weeks of implantation in sheep. These results suggest that the DPR cables may safely be used as a sublaminar wire, and substantiate controlled clinical trials. The low-profile $(4 \times$ $0.75 \mathrm{~mm}$ for a double looped cable) and high strength of the UHMWPE cables provide substantial benefits in comparison to other materials and allows for widespread application in the orthopedic field, for example in cerclage cable applications.

\section{ACKNOWLEDGMENTS}

The authors thank Armand Wintjens, Ferry Soeters (DSM Biomedical), and Virginia Ballotta (Eindhoven University of Technology) for their help and support with the mechanical tests, and Fenneke Linker and Judith Muijtjens (DSM) for their toxicology expertise and help and support with the leaching tests, respectively.

\section{REFERENCES}

1. Liljenqvist UR, Link TM, Halm HF. Morphometric analysis of thoracic and lumbar vertebrae in idiopathic scoliosis. Spine (Phila Pa 1976) 2000;25:1247-1253.

2. Parent $S$, Labelle $H$, Skalli $W$, de Guise J. Thoracic pedicle morphometry in vertebrae from scoliotic spines. Spine (Phila $\mathrm{Pa}$ 1976) 2004;29:239-248. 
3. Di Silvestre M, Parisini P, Lolli F, Bakaloudis G. Complications of thoracic pedicle screws in scoliosis treatment. Spine (Phila $\mathrm{Pa}$ 1976) 2007:32:1655-1661.

4. Raney EM. Hooks and wires-tried and true plus how to: POSNA1DayCourse, April 29, 2009. J Pediatr Orthop 2011;31(1 Suppl):S81-S87.

5. Polly DW, Jr, Potter BK, Kuklo T, Young S, Johnson C, Klemme WR. Volumetric spinal canal intrusion: a comparison between thoracic pedicle screws and thoracic hooks. Spine (Phila Pa 1976) 2004;29:63-69.

6. van Laar W, Meester RJ, Smit TH, van Royen BJ. A biomechanical analysis of the self-retaining pedicle hook device in posterior spinal fixation. Eur Spine J 2007;16:1209-1214.

7. Hitchon PW, Brenton MD, Black AG, From A, Harrod JS, Barry C, Serhan H, Torner JC. In vitro biomechanical comparison of pedicle screws, sublaminar hooks, and sublaminar cables. J Neurosurg 2003;99(1 Suppl):104-109.

8. Hamasaki T, Tanaka N, Kim J, Okada M, Ochi M, Hutton WC. Pedicle screw augmentation with polyethylene tape: a biomechanical study in the osteoporotic thoracolumbar spine. J Spinal Disord Tech 2010;23:127-132.

9. Reames DL, Smith JS, Fu KM, Polly DW, Jr, Ames CP, Berven SH, Perra JH, Glassman SD, McCarthy RE, Knapp RD, Jr, Heary R, Shaffrey $\mathrm{Cl}$. Complications in the surgical treatment of 19,360 cases of pediatric scoliosis: a review of the Scoliosis Research Society Morbidity and Mortality database. Spine (Phila Pa 1976) 2011;36:1484-1491.

10. Songer MN, Spencer DL, Meyer PR, Jr, Jayaraman G. The use of sublaminar cables to replace Luque wires. Spine (Phila Pa 1976) 1991;16(8 Suppl):S418-S421.

11. Weiss HR. Is there a body of evidence for the treatment of patients with Adolescent Idiopathic Scoliosis (AIS)? Scoliosis 2007;2:19.

12. Huhn SL, Wolf AL, Ecklund J. Posterior spinal osteosynthesis for cervical fracture/dislocation using a flexible multistrand cable system: technical note. Neurosurgery 1991;29:943-946.

13. Parsons JR, Chokshi BV, Lee CK, Gundlapalli RV, Stamer D. The biomechanical analysis of sublaminar wires and cables using luque segmental spinal instrumentation. Spine (Phila Pa 1976) 1997:22:267-273.

14. Gazzeri R, Faiola A, Galarza M, Tamorri M. Universal Clamp system in thoracolumbar spinal fixation: technical note. Acta Neurochir (Wien) 2009;151:1673-1680.

15. Mazda K, Ilharreborde B, Even J, Lefevre Y, Fitoussi F, Pennecot GF. Efficacy and safety of posteromedial translation for correction of thoracic curves in adolescent idiopathic scoliosis using a new connection to the spine: the Universal Clamp. Eur Spine J 2009; 18:158-169.

16. Takahata $M$, Ito $M$, Abumi $K$, Kotani $Y$, Sudo $H$, Ohshima $S$ Minami A. Comparison of novel ultra-high molecular weight polyethylene tape versus conventional metal wire for sublaminar segmental fixation in the treatment of adolescent idiopathic scoliosis. J Spinal Disord Tech 2007;20:449-455.

17. Imagama S, Ito Z, Wakao N, Ando K, Hirano K, Tauchi R, Muramoto A, Matsui $H$, Matsumoto T, Sakai $Y$ and others. Posterior surgery for adolescent idiopathic scoliosis with pedicle screws and ultra-high molecular weight polyethylene tape: Achieving the ideal thoracic kyphosis. Clin Spine Surg 2016;29: E376-E383.

18. Jouve JL, de Gauzy JS, Blondel B, Launay F, Accadbled F, Bollini G. Use of the Universal Clamp for deformity correction and as an adjunct to fusion: preliminary results in scoliosis. J Child Orthop 2010;4:73-80.

19. Sale de Gauzy J, Jouve JL, Accadbled F, Blondel B, Bollini G. Use of the Universal Clamp in adolescent idiopathic scoliosis fo deformity correction and as an adjunct to fusion: 2-year followup. J Child Orthop 2011;5:273-282.

20. Roth $A K$, van der Veen AJ, Bogie $R$, Willems $P C$, van Rietbergen $B$, van Rhijn LW, Arts JJ. Range of motion in segmental versus nonsegmental ultrahigh molecular weight polyethylene sublaminar wire growth guidance type constructs for early-onset scoliosis correction. Spine (Phila Pa 1976) 2015;40:E1212-E1218.

21. Bogie $R$, Roth $A$, Faber $S$, de Jong J, Welting $T$, Willems $P$, Arts J, van Rhijn L. Novel radiopaque UHMWPE sublaminar wires in a growth-guidance system for the treatment of early onset scoliosis: Feasibility in a large animal study. Spine 2014;39:E1503E1509.

22. Dickman CA, Papadopoulos SM, Crawford NR, Brantley AG, Gealer RL. Comparative mechanical properties of spinal cable and wire fixation systems. Spine (Phila Pa 1976) 1997;22:596-604.

23. Slikkerveer A, de Wolff FA. Pharmacokinetics and toxicity of bismuth compounds. Med Toxicol Adverse Drug Exp 1989;4:303-323.

24. Canena J, Reis J, Pinto AS, Santos AM, Leitao J, Pinheiro T, Quina MG. Distribution of bismuth in the rat after oral dosing with ranitidine bismuth citrate and bismuth subcitrate. J Pharm Pharmacol 1998;50:279-283.

25. Lee SP, Lim TH, Pybus J, Clarke AC. Tissue distribution of orally administered bismuth in the rat. Clin Exp Pharmacol Physiol 1980;7:319-324.

26. Taylor EG, Klenerman P. Acute renal failure after colloidal bismuth subcitrate overdose. Lancet 1990;335:670-671.

27. Briand GG, Burford N. Bismuth compounds and preparations with biological or medicinal relevance. Chem Rev 1999;99:2601-2658.

28. Sun $\mathrm{H}$, Li H, Harvey I, Sadler PJ. Interactions of bismuth complexes with metallothionein(II). J Biol Chem 1999;274:29094-29101.

29. Roberts HW, Toth JM, Berzins DW, Charlton DG. Mineral trioxide aggregate material use in endodontic treatment: a review of the literature. Dent Mater 2008;24:149-164

30. Torabinejad M, Parirokh $\mathrm{M}$. Mineral trioxide aggregate: a comprehensive literature review-part II: leakage and biocompatibility investigations. J Endod 2010;36:190-202.

31. Deb S, Abdulghani S, Behiri JC. Radiopacity in bone cements using an organo-bismuth compound. Biomaterials 2002;23:33873393.

32. Hernandez L, Fernandez M, Collia F, Gurruchaga M, Goni I. Preparation of acrylic bone cements for vertebroplasty with bismuth salicylate as radiopaque agent. Biomaterials 2006;27:100-107.

33. Braz MG, Marcondes JP, Matsumoto MA, Duarte MA, Salvadori DM, Ribeiro DA. Genotoxicity in primary human peripheral lymphocytes after exposure to radiopacifiers in vitro. $\mathrm{J}$ Mater Sci Mater Med 2008;19:601-605.

34. Rodilla V, Miles AT, Jenner W, Hawksworth GM. Exposure of cultured human proximal tubular cells to cadmium, mercury, zinc and bismuth: toxicity and metallothionein induction. Chem Biol Interact 1998;115:71-83.

35. Zeferino EG, Bueno CE, Oyama LM, Ribeiro DA. Ex vivo assessment of genotoxicity and cytotoxicity in murine fibroblasts exposed to white MTA or white Portland cement with $15 \%$ bismuth oxide. Int Endod J 2010;43:843-848.

36. Sano $Y$, Satoh $H$, Chiba M, Okamoto $M$, Serizawa $K$, Nakashima $\mathrm{H}$, Omae K. Oral toxicity of bismuth in rat: single and 28-day repeated administration studies. J Occup Health 2005;47:293-298.

37. Bradley B, Singleton M, Lin Wan Po A. Bismuth toxicity-a reassessment. J Clin Pharm Ther 1989;14:423-441.

38. Serfontein WJ, Mekel R. Bismuth toxicity in man II. Review of bismuth blood and urine levels in patients after administration of therapeutic bismuth formulations in relation to the problem of bismuth toxicity in man. Res Commun Chem Pathol Pharmacol 1979;26:391-411. 